\title{
Pengukuran Efisiensi Serta Analisis Faktor Internal dan Eksternal Bank yang Memengaruhinya
}

\author{
Measurement of Efficiency and Analysis of Bank Internal and External Factors that \\ Affect It
}

\author{
Aron Marsondang ${ }^{1 *}$, Budi Purwanto ${ }^{2}$, Heti Mulyati ${ }^{2}$ \\ ${ }^{1}$ Departemen Manajemen, Fakultas Ekonomi dan Manajemen, IPB Kampus Dramaga Bogor 16680 \\ ${ }^{2}$ Sekolah Pascasarjana Institut Pertanian Bogor, Kampus IPB Dramaga, Bogor 16680
}

\begin{abstract}
Efficiency for the banking industry as a whole is the most important aspect considered to realize healthy and sustainable financial performance. Therefore, to realize a healthy and sustainable financial performance, the government intervenes in the banking business to divide or categorize banks based on core capital. This study will measure the efficiency level of conventional commercial banks with input variables that are thought to affect the output variable using non-parametric methods with the Data Envelopment Analysis (DEA) model. Bank size (SIZE), Capital Adequacy Ratio (CAR), and Loan to Deposit Ratio (LDR) proved to have a significant positive effect on the efficiency of banks listed on the Indonesia Stock Exchange for the period 2013-2017. Meanwhile, non-performing loan (NPL) proved to have a significant negative effect on the efficiency of banks listed on the Indonesia Stock Exchange for the period 2013-2017. External factors such as the rupiah exchange rate (KURS), Bank Indonesia interest rates (SBI), and gross domestic product (GDP) have proven to have no significant positive effect on the efficiency of banks listed on the Indonesian Stock Exchange in the period 2013-2017.
\end{abstract}

Keywords: Bank size, Capital Adequacy Ratio (CAR), Non-Performing Loan (NPL), Loan to Deposit Ratio (LDR), Rupiah exchange rate (KURS), Bank Indonesia interest rate (SBI), Gross Domestic Gross (GDP), efficiency level banking.

\begin{abstract}
ABSTRAK
Efisiensi bagi industri perbankan secara keseluruhan adalah aspek terpenting yang dipertimbangkan untuk mewujudkan kinerja keuangan yang sehat dan berkelanjutan. Oleh sebab itu, untuk mewujudkan kinerja keuangan yang sehat dan berkelanjutan, pemerintah melakukan intervensi dalam bisnis perbankan untuk membagi atau mengategorikan bank berdasarkan modal inti. Penelitian ini akan mengukur tingkat efisiensi bank umum konvensional dengan variabel input yang diduga mempengaruhi variabel output dengan menggunakan metode nonparametric dengan model Data Envelopment Analysis (DEA). Ukuran bank (SIZE), Capital Adequacy Ratio (CAR), dan Loan to Deposit Ratio (LDR) terbukti memiliki pengaruh positif yang signifikan terhadap efisiensi bank yang terdaftar di Bursa Efek Indonesia untuk periode 2013-2017. Sementara itu, Non Performing Loan (NPL) terbukti memiliki pengaruh negatif yang signifikan terhadap efisiensi bank yang terdaftar di Bursa Efek Indonesia untuk periode 2013-2017. Faktor-faktor eksternal seperti nilai tukar rupiah (KURS), suku bunga Bank Indonesia (SBI), dan produk domestik bruto (PDB) terbukti tidak memiliki pengaruh positif yang signifikan terhadap efisiensi bank yang terdaftar di Bursa Efek Indonesia pada periode 2013 -2017.
\end{abstract}

Kata Kunci: Ukuran bank, Capital Adequacy Ratio (CAR), Non-Performing Loan (NPL), Loan to Deposit Ratio (LDR), nilai tukar rupiah (KURS), suku bunga Bank Indonesia (SBI), Gross Domestic Bruto (GDP), tingkat efisiensi perbankan.

*Corresponding author

Alamat e-mail: marsondang@gmail.com 


\section{PENDAHULUAN}

Sektor perbankan merupakan lembaga yang berperan penting sebagai penggerak perekonomian nasional. Bank sebagai agen pembangunan diharapkan mampu memelihara kestabilan moneter. Salah satunya dilakukan dengan mengatur perputaran uang di masyarakat melalui peranan bank sebagai perantara keuangan (financial intermediary). Lebih lanjut, sebagai intermediasi keuangan, bank memiliki peranan sebagai mata rantai dalam melakukan bisnis yang berkaitan dengan penyediaan atau pendanaan dan modal kerja bagi unit bisnis dalam melaksanakan fungsi produksi.

Di Indonesia, perbankan mempunyai pangsa pasar sebesar 80 persen (Sutanto, 2015). Dari keseluruhan sistem keuangan yang ada, kurang lebih 90 persen dari jumlah aset dan total pembiayaaan dikuasai oleh Bank Umum (Bank Indonesia, 2016). Namun demikian, berdasarkan data dari statistik perbankan yang dipublikasikan oleh Otoritas Jasa Keuangan (OJK) diketahui bahwa setiap tahunnya biaya operasional perbankan umum mengalami peningkatan seperti terlihat pada gambar di bawah ini.

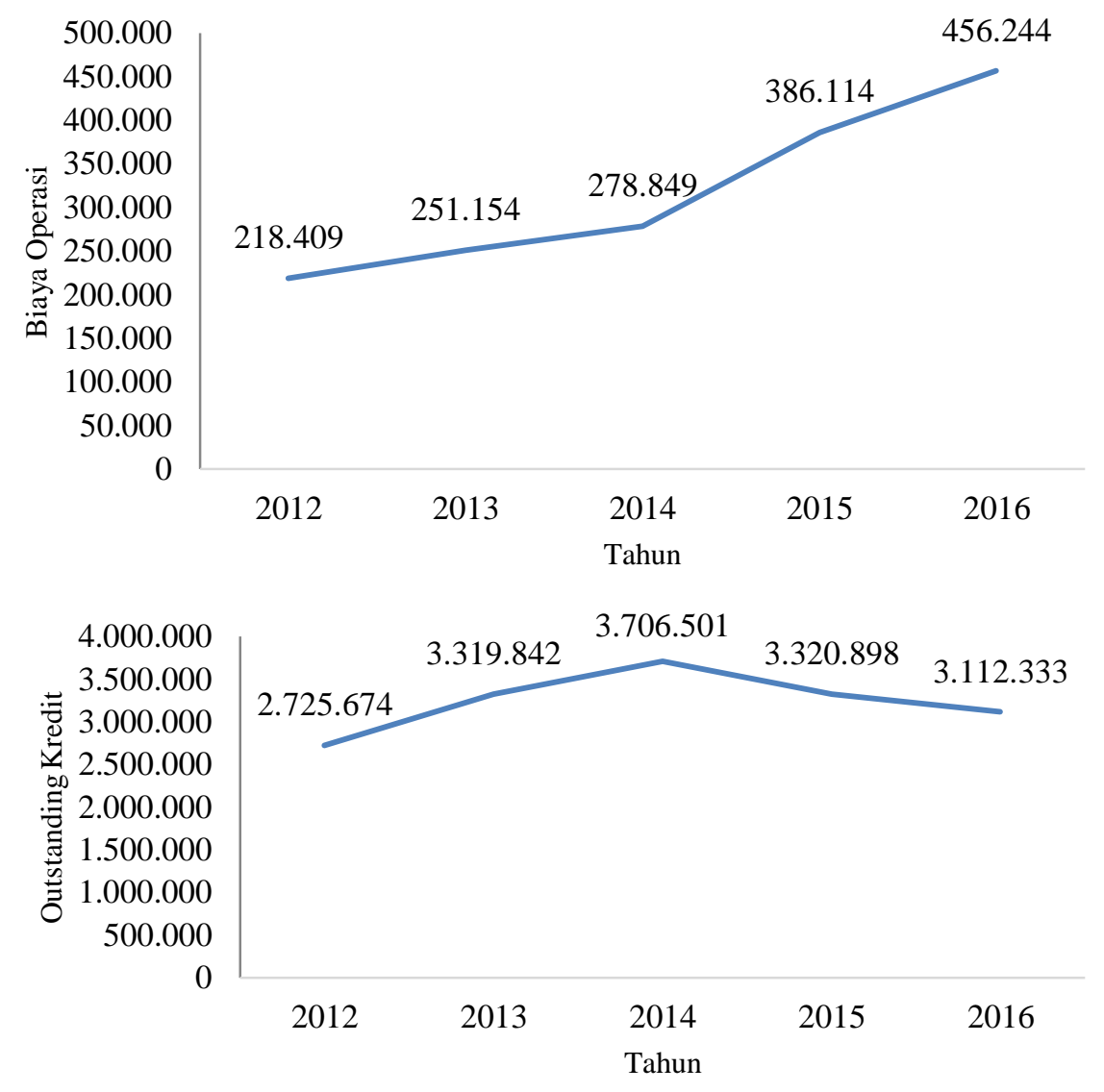

Gambar 1. Trend nilai biaya operasional dan outstanding kredit perbankan umum periode 2012-2016 (Dalam Miliar Rupiah)

Sumber: Otoritas Jasa Keuangan (2019)

Mengacu pada data diatas, dapat diketahui bahwa hampir setiap tahunnya perbankan mengalami peningkatan biaya operasional. Pada tahun 2012, nilai biaya operasional perbankan umum sebesar 218.409 miliar rupiah dan terus mengalami peningkatan. Berdasarkan data dari OJK tersebut, peningkatan tertinggi biaya operasional perbankan terjadi pada tahun 2016 yang mencapai 456.244 miliar rupiah atau meningkat sebesar 108,9 persen dibandingkan dengan empat tahun sebelumnya. Dengan kata lain, trend biaya operasional perbankan di Indonesia yang memiliki pangsa pasar sebesar 80 persen dalam melaksanakan operasionalnya masih dihadapkan dengan masalah tingginya biaya operasional. Kondisi tersebut juga menunjukkan

Jurnal Manajemen dan Organisasi JMO), Vol. 10 No. 1,
April 2019 , April 2019,
Hal. 48-62 
adanya gap dan atau arah berlawanan dengan outstanding kredit selama periode 2012 sampai dengan 2016. Pada tahun 2015, biaya operasional mengalami peningkatan yang cukup signifikan dibandingkan dengan tahun 2014, sedangkan pada tahun yang sama yaitu tahun 2015 outstanding kredit mengalami penurunan mencapai 10,40 persen dibandingkan tahun 2014. Adanya gap antara biaya operasional yang dikeluarkan perbankan dengan outstanding kredit menjadikan hal tersebut perhatian penting untuk diketahui penyebabnya. Oleh karena itu, analisis mengenai efisiensi pada perusahaan sektor perbankan perlu dilakukan guna mencari tahu faktor-faktor apa saja yang dapat mempengaruhi tingkat efisiensi perbankan tersebut. Lebih lanjut, pentingnya pengukuran efisiensi adalah untuk memungkinkan para manajer untuk melakukan tolok ukur kinerja bank dan mendefinisikan bidang-bidang inefisiensi untuk perbaikan dimasa depan (Mostafa dalam Othman et al., 2016).

Terkait dengan urgensi analisis efisiensi pada sektor perbankan, mengacu pada Muljawan et al. (2014), dinyatakan bahwa daya saing perbankan dapat tercermin dari tingkat efisiensi operasional. Oleh sebab itu, penting untuk diketahui faktor-faktor yang dapat mempengaruhi tingkat efisiensi pada perusahaan sektor perbankan. Lebih lanjut, efisiensi juga sering dijadikan sebagai salah satu alat utama dalam mengukur kinerja perusahaan (Andhyka et al., 2017). Hal tersebut juga terjadi pada perusahaan perbankan. Lebih dari itu, pada industri perbankan, efisiensi tidak hanya digunakan dalam melihat kinerja operasional dan manajemen, melainkan efisiensi berperan penting dalam melihat kemungkinan suatu perusahaan perbankan mengalami kebangkrutan. Hal ini sesuai denganyang dinyatakan oleh Berger et al. (1993) bahwa rendahnya tingkat efisiensi merupakan salah satu indikasi akan terjadinya kebangkrutan suatu bank. Oleh sebab itu, mengetahui tingkat efisiensi suatu bank menjadi penting.

Efisiensi merupakan indikator penting dalam mengukur kinerja keseluruhan dari aktivitas suatu perusahaan. Menurut Haynes (1999), efisiensi diartikansebagai bagaimana suatu perusahaan dapat berproduksi dengan biaya serendah mungkin untuk menghasilkan output secara optimal. Perusahaan dikatakan efisien apabila dengan jumlah input tertentu dapat menghasilkan jumlah output lebih banyak atau pada jumlah output tertentu bisa menggunakan input lebih sedikit. Pada dasarnya, efisiensi diartikan sebagai sebagai rasio output terhadap input; dan lebih banyak output per unit input menunjukkan efisiensi yang lebih besar sementara output maksimum per unit input mencerminkan efisiensi optimal (Othman et al., 2016). Pengukuran efisiensi menentukan bagaimana perusahaan dapat memaksimalkan output dan laba dan pada saat yang sama meminimalkan biayanya. Konsep pengukuran efisiensi menurut Sherman dan Zhu (2006) dalam Othman et al. (2016) menyatakan bahwa efisiensi suatu perusahaan terdiri atas empat jenis yaitu: pertama, technical efficiency (TE) yang merupakan efisiensi global dalam mengukur kemampuan bank untuk menghasilkan output aktual dengan input lebih sedikit, atau lebih sedikit sumber daya yang digunakan menunjukkan efisiensi yang lebih tinggi. Kedua, scale efficiency (SE) mengacu pada tingkat volume aktivitas optimal dimana inefisiensi dapat timbul jika barang atau jasa diproduksi diatas atau dibawah tingkat optimal yang menghasilkan tambahan biaya tetap. Ketiga, price efficiency (PE) dimana bank dapat meningkatkan efisiensinya jika dapat membeli input (sumber daya manusia dan material) dengan harga lebih murah tanpa mengorbankan kualitas. Keempat, allocative efficiency (AE) mengukur campuran optimal dari beberapa input untuk menghasilkan produk atau layanan, seperti bank memasukkan automatic teller machines (ATM) dan internet banking untuk pertukaran tenaga kerja modal untuk meningkatkan efisiensi. Dengan demikian, dapat dipahami bahwa suatu proses produksi dikatakan efisien apabila pada penggunaan input sejumlah tertentu dapat dihasilkan output yang maksimal, atau untuk menghasilkan output sejumlah tertentu digunakan input yang paling minimal.

Salah satu analisis mengenai efisiensi yang digunakan oleh para peneliti terdahulu adalah Data Envelopment Analysis (DEA) (Endri dan Abidin, 2009; Wijayanto dan Sutarno, 2010;

Kumar dan Charles, 2012; \& Gardener et al., 2013). Data Envelopment Analysis (DEA) merupakan metode non-parametik yang menghasilkan production frontier untuk mengidentifikasi unit yang digunakan sebagai referensi yang dapat membantu untuk mencari penyebab dan jalan keluar dari ketidakefisienan. Dengan analisis efisiensi perbankan 
berdasarkan model DEA, dapat diketahui input dan atau output yang menyebabkan bank menjadi tidak efisien. Karakter pengukuran efisiensi dengan metode DEA memiliki konsep yang berbeda dengan efisiensi pada umumnya yaitu efisiensi yang diukur adalah bersifat teknis, bukan ekonomis, artinya bahwa analisis DEA hanya memperhitungkan nilai absolut dari satu variabel. Model DEA memiliki dua pendekatan yang terdiri dari pendekatan orientasi input (input oriented) dan pendekatan orientasi output (output oriented) (Charnes et al., 1978). Selanjutnya menurut Hadad et al. (2003), pendekatan yang digunakan dalam mendefinisikan hubungan input output dalam tingkah laku perbankan pada metode parametrik maupun nonparametrik adalah pendekatan produksi (the production approach), pendekatan intermediasi (the intermediation approach); dan pendekatan aset (the asset approach). Pemilihan input dan output yang tepat dalam penerapan analisis DEA merupakan langkah yang krusial. Hal ini mengingat bahwa terdapat pendekatan yang berbeda-beda dalam analisis DEA. Pendekatan yang berbeda-beda dalam analisis DEA menyebabkan bahwa variabel input output analisis DEA juga beragam. Pada penelitian ini akan digunakan pendekatan intermediasi karena mempertimbangkan fungsi vital bank sebagai lembaga intemediaris yang menghimpun dana dari surplus unit dan menyalurkannya kepada defisit unit. Berger dan Mester (1997) menyatakan bahwa pendekatan intermediasi merupakan pendekatan yang lebih tepat untuk mengevaluasi kinerja lembaga keuangan secara umum karena karakteristik lembaga keuangan sebagai financial intermediation. Hal ini pun sejalan dengan beberapa penelitian seperti pada penelitian Avkira (1999), Erwinta dan Wilson (2004) yang menghitung efisiensi operasional dengan menggunakan pendekatan intermediaris dalam menentukan variabel output oriented.

Besarnya tingkat efisiensi pada perusahaan perbankan akan sangat bergantung pada berbagai faktor, baik yang bersifat mikro maupun makro (Berger \& Mester, 1997; Muljawan et al., 2014). Faktor-faktor tersebut di antaranya adalah suku bunga, pertumbuhan ekonomi, volatilitas pasar, tingkat harga tenaga kerja, biaya energi, dan faktor-faktor lainnya. Lebih lanjut, di antara faktor-faktor penentu efisiensi tersebut, tingkat suku bunga dana di pasar merupakan salah satu faktor yang sangat menentukan tingkat efisiensi operasional bank karena menentukan besarnya cost of fund bank (Muljawan et al., 2014). Selain itu, tingkat persaingan supply kredit yang menentukan pola pembentukan pasar kredit juga berpengaruh terhadap efisiensi operasional perbankan. Dalam suatu pasar yang mengalami supply rigidity, supply kredit akan cenderung didominasi oleh beberapa bank, sehingga lembaga perbankan akan dapat memaksimalkan keuntungan jangka pendek. Namun, secara jangka panjang bank-bank tersebut akan kehilangan daya kompetitifnya untuk bersaing secara efisien. Dampak lebih luasnya adalah masyarakat selaku pengguna dana akan mengalami kesulitan untuk mendapatkan sumber dana yang murah untuk menjalankan usahanya dan pada akhirnya juga akan menentukan daya saing industri dalam negeri.

Pengukuran efisiensi perbankan yang menjadi fokus penelitian ini adalah technical efficiency (efisiensi teknikal). Efisiensi teknikal pada dasarnya menyatakan hubungan antara input dengan output dalam suatu proses produksi (Berger, 1997). Selain itu sangat penting mengetahui faktor-faktor yang secara langsung dapat mempengaruhi tingkat efisiensi bank untuk melihat faktor determinasi mana yang membuat kinerja bank tidak efisien. Penelitian yang dilakukan Anwar et al. (2012) menjelaskan faktor-faktor yang memengaruhi efisiensi operasional bank di Indonesia di antaranya adalah total aset sebagai proksi dari ukuran bank, Return on Asset (ROA) sebagai proksi dari keuntungan bank, Capital Adequacy Ratio (CAR) dan Loan to Deposit Ratio (LDR) sebagai proksi dari likuiditas bank, Non Performing Loan (NPL) sebagai proksi dari risiko kredit bank, pertumbuhan GDP riil, IHSG (Indeks Harga Saham Gabungan), dan nilai tukar rupiah terhadap dolar. Sedangkan pada penelitian Subandi (2014), dilakukan analisis faktor-faktor yang memengaruhi efisiensi operasional bank di Indonesia yang di antaranya adalah total aset, tipe bank (status bank), rasio CAR, rasio LDR, rasio NPL, pengeluaran operasional (operating expense), dan Net Interest Margin (NIM). Penelitian yang dilakukan oleh Herlina (2006) menunjukkan bahwa ukuran perusahaan memiliki hubungan positif dengan tingkat efisiensi bank. 
Efisiensi bagi industri perbankan secara keseluruhan merupakan aspek yang paling penting diperhatikan untuk mewujudkan suatu kinerja keuangan yang sehat dan berkelanjutan (sustainable). Oleh sebab itu, untuk mewujudkan suatu kinerja keuangan yang sehat dan berkelanjutan (sustainable) pemerintah mengintervensi usaha perbankan melakukan pembagian atau kategorisasi bank berdasarkan modal inti. Hal tersebut mulai diterapkan oleh Bank Indonesia pada tahun 2012 yang tertuang dalam Peraturan Bank Indonesia Nomor 14/26/PBI/2012 tentang Kegiatan Usaha dan Jaringan Kantor berdasarkan Modal Inti Bank yang kemudian diperbaharui menjadi Peraturan Otoritas Jasa Keuangan No. 6/POJK.3/2016. Peraturan tersebut membagi bank umum berdasarkan modal inti yang dimilikinya dan disebut dengan BUKU (Bank Umum berdasarkan Kegiatan Usaha). Untuk bank dengan modal inti dibawah Rp 1 Triliun, bank masuk dalam kategori BUKU I. Sedangkan untuk bank dengan modal inti mulai dari Rp 1 triliun hingga di bawah Rp 5 triliun, masuk dalam kategori BUKU II. Bank dengan modal inti antara Rp 5 triliun hingga di bawah Rp 30 triliun, dikategorikan sebagai bank BUKU III. Bank dengan modal inti di mulai dari Rp 30 triliun hingga diatasnya masuk dalam kategori bank BUKU IV (Bank Indonesia, 2012).

Merujuk pada kondisi tersebut, penelitian ini hanya melakukan kategori bank BUKU III dan BUKU IV dimana dalam penelitian yang dilakukan oleh Nisa et al. (2018) ditekankan bahwa bank dengan modal inti yang lebih tinggi beroperasi lebih efisien daripada bank dengan modal inti rendah. Dengan demikian, diharapkan bank dengan BUKU tinggi memiliki nilai efisiensi yang juga tinggi. Kemudian, sejalan dengan beberapa penelitian terdahulu, maka penelitian ini akan menganalisa pengaruh faktor-faktor internal dan eksternal bank yang diduga dominan berpengaruh terhadap technical efficiency perbankan. Penentuan faktor internal dan eksternal bank pada penelitian ini juga didasarkan pada faktor yang mempengaruhi secara langsung fungsi intermediasi bank. Sehingga faktor internal bank seperti ukuran bank (SIZE), Capital Adequacy Ratio (CAR), risiko kredit (Non Performing Loan), dan liquidity (Loan to Deposit) yang diduga secara langsung berpengaruh terhadap fungsi intermediasi bank yang optimal, juga mempengaruhi tingkat efisiensi suatu bank. Sedangkan faktor eksternal bank dalam penelitian ini antara lainnya adalah nilai tukar rupiah, suku bunga bank Indonesia, dan Growth Domestic Product (GDP).

\section{METODE PENELITIAN}

\section{Data Envelopment Analysis (DEA)}

Metode Data Envelopment Analysis (DEA) merupakan prosedur yang dirancang secara khusus untuk mengukur nilai efisiensi suatu kegiatan ekonomi yang menggunakan banyak inputdan menghasilkan banyak output. DEA merupakan suatu pendekatan non-parametrik berbasis linear programing (LP) yang dapat digunakan untuk mengukur efisiensi pada Unit Kegiatan Ekonomi (UKE) atau yang sering disebut Decision Making Unit (DMU) yang memiliki beragam input dan output. Metode DEA pada penelitian ini berorientasi pada output (output oriented) yaitu dengan input yang tetap dapat menghasilkan output yang besar. Menurut Banker, et al. (1984), asumsi DEA yang berorientasi pada output tepat digunakan bagi perbankan yang beroperasi pada skala yang optimal.

\section{Oriented ouput}

Variabel yang digunakan sebagai input dan output dalam model DEA mengacu pada hasil penelitian Hadad (2003). Selain itu, pemilihan variabel input dan output tersebut juga didasarkan pada peran industri perbankan sebagai lembaga intermediasi. Variabel yang digunakan sebagai input di antaranya adalah Dana Pihak Ketiga (DPK), beban tenaga kerja (BTK), dan Total Aset, sedangkan output terdiri atas kredit dan pendapatan operasional.

\section{Model Regresi Data Panel}

Metode analisis data digunakan juga untuk menguji hipotesa dalam penelitian ini adalah 
(2018:83), data panel adalah penggabungan antara data cross-section dan data time series. Adapun persamaan regresi data panel dalam penelitian ini adalahsebagai berikut:

$$
\begin{gathered}
\mathrm{EF}_{\mathrm{it}}=\beta_{0}+\beta_{1}(\mathrm{SIZE})_{\mathrm{it}}+\beta_{2}(\mathrm{CAR})_{\mathrm{it}}+\beta_{3}(\mathrm{NPL})_{\mathrm{it}}+\beta_{4}(\mathrm{LDR})_{\mathrm{it}}+\beta_{5}(\mathrm{KURS})_{\mathrm{it}}+\beta_{6}(\mathrm{SBI})_{\mathrm{it}}+\beta_{7} \\
(\mathrm{GDP})_{\mathrm{it}}+\mu_{\mathrm{it}}
\end{gathered}
$$

Keterangan:

$$
\begin{array}{ll}
\mathrm{EF} & =\text { Skor DEA (tingkat efisiensi) } \\
\mathrm{SIZE} & =\text { Total Aset Bank } \\
\mathrm{CAR} & =\text { Capital Adequacy Ratio } \\
\mathrm{NPL} & =\text { Non Performing Loan } \\
\mathrm{LDR} & =\text { Loan to Deposit Ratio } \\
\mathrm{KURS} & =\text { Nilai Tukar Rupiah terhadap Dollar Amerika } \\
\mathrm{SBI} & =\text { Suku Bunga Bank Indonesia } \\
\mathrm{GDP} & =\text { Gross Domestic Product }
\end{array}
$$

Dalam regresi data panel dikenal tiga macam pendekatan (Gujarati, 2003) yang terdiri dari pendekatan kuadrat terkecil atau pooled least square (common effect), pendekatan efek tetap (fixed effect), dan pendekatan efek random (random effect). Berikut ini merupakan tahapan analisis data dan pengujiannya yang dilakukan pada penelitian ini.

1. Common effect Model (CEM)

Common effect model (CEM) atau pooled least square (PLS) merupakan model yang diperoleh dengan mengombinasikan atau mengumpulkan semua data cross section dan data time series. Model data ini kemudian diestimasi dengan menggunakan ordinary leastsquare (OLS).

\section{Fixed Effect Model (FEM)}

Fixed effect model (FEM) digunakan untuk mengatasi masalah asumsi intersep atau slope dari persamaan regresi yang dianggap konstan pada model pooled least square (PLS). Dalam metode ini variabel dummy (dummy variable) digunakan untuk menghasilkan nilai parameter yang berbeda-beda, baik lintas unit cross section maupun antar waktu (time series).

3. Random Effect Model (REM)

Random effect model (REM) digunakan untuk mengestimasi data panel dimana variabel gangguan mungkin saling berhubungan antar waktu dan antar individu. Dalam model ini, parameter yang berbeda antar waktu maupun antar individu dimasukkan ke dalam error, karena hal inilah model ini sering juga disebut sebagai Error Component Model (ECM).

4. Pemilihan Model Estimasi Data Panel

Dari ketiga pendekatan model data panel di atas, maka untuk menentukan pendekatan mana yang lebih baik digunakan pengujian kesesuaian model. Secara formal, ada tiga prosedur pengujian kesesuaian model yang akan digunakan untuk memilih model regresi data panel yang terbaik, yang terdiri dari Uji Chow (Chow Test), Uji Hausman (Hausman Test) dan Uji Lagrange Multiplier (Lagrange Multiplier Test). Berikut ini dijelaskan mengenai ketiga pengujian tersebut.

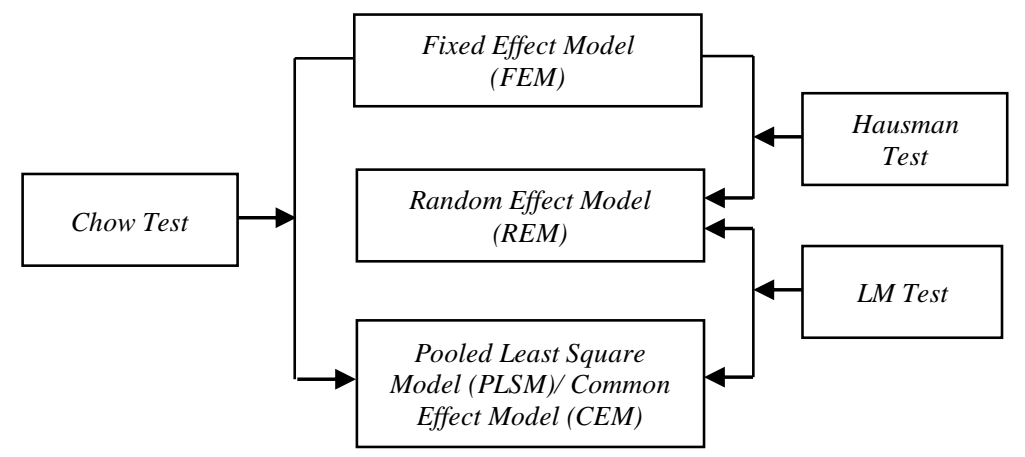

Gambar 2. Pengujian Kesesuaian Model

Jurnal Manajemen dan Organisas (JMO), Vol. 10 No. 1 , April 2019, 
a. Uji Chow (Chow Test)

Uji Chow (Chow Test) atau uji Restricted $\mathrm{F}$ digunakan untuk memilih model mana yang paling baik digunakan untuk mengestimasi data panel apakah fixed effect model (FEM) atau common effect model (CEM). Rumus untuk mendapatkan nilai F Statistik seperti yang dirumuskan oleh Chow adalah sebagai berikut:

Dimana:

$$
F=\frac{P R S S-U R S S /(N-1)}{\operatorname{URSS}(N T-N-K)}
$$

$$
\begin{array}{ll}
\text { PRSS } & =\text { Residual Sum of Square }(\mathrm{CEM}) \\
\mathrm{URSS} & =\text { Residual Sum of } \text { Square }(\mathrm{FEM}) \\
\mathrm{N} & =\text { jumlah data } \text { cross section } \\
\mathrm{T} & =\text { jumlah data time series } \\
\mathrm{K} & =\text { jumlah variabel bebas }
\end{array}
$$

Hipotesis nol dari restricted $F$ test adalah sebagai berikut:

$\mathrm{H}_{\mathrm{o}}=$ Common effect model (CEM) lebih baik dari fixed effectmodel (FEM)

$\mathrm{H}_{1}=$ Fixed effectmodel (FEM) lebih baik dari common effect model (CEM)

Kriteria pengujian hipotesis adalah jika hasil nilai Fhitung > Ftabel pada tingkat keyakinan $\alpha$ tertentu, maka Ho ditolak, H1 diterima, artiya fixed effect model lebih tepat digunakan untuk teknik estimasi (Gujarati, 2003).

b. Uji Hausman (Hausman Test)

Uji Hausman (Hausman Test) digunakan untuk memilih model mana yang paling baik digunakan untuk mengestimasi data panel apakah fixed effectmodel (FEM) atau random effectmodel (REM). Rumus untuk mendapatkan nilai uji Hausman adalah sebagai berikut:

Dimana:

$$
m=(\beta-\mathrm{b})\left(M_{0}-M_{1}\right)^{-1}(\beta-\mathrm{b}) \approx X_{2}(\mathrm{~K})
$$

$\beta=$ vector untuk statistik variabel fixed effect

$\mathrm{b} \quad=$ vector untuk statistik variabel random effect

$M_{0} \quad$ = matrik kovarian untuk dugaan FEM

$M_{l} \quad$ = matrik kovarian untuk dugaan REM

Hipotesis nol dari uji Hausman adalah sebagai berikut:

$\mathrm{H}_{0}$ : Random effect model (REM) lebih baik dari fixed effectmodel (FEM)

$\mathrm{H}_{1}$ : Fixed effectmodel (FEM) lebih baik dari common effect model (CEM)

Kriteria pengujian hipotesis adalah jika $X^{2}{ }_{\text {hitung }}>X^{2}$ tabel dan $p$-value signifikan, maka $\mathrm{H}_{0}$ ditolak danfixed effect model tepat untuk digunakan (Gujarati, 2003).

c. Uji Lagrange Multiplier (Lagrange Multiplier Test)

Uji Lagrange Multiplier (Lagrange Multiplier Test)atauLM Test digunakan untuk memilih model mana yang paling baik digunakan untuk mengestimasi data panel apakah random effectmodel (REM) atau common effectmodel (CEM).Rumus untuk mendapatkan nilai uji Lagrange Multiplier adalah sebagai berikut:

$$
L M=\frac{n T}{2(T-1)}\left[\frac{\sum_{i=1}^{n}\left(\sum_{t=1}^{T} e_{i t}\right)^{2}}{\sum_{i=1}^{n} \sum_{t=1}^{T} e_{i t}^{2}}-1\right]^{2}
$$

Hipotesis nol dari LM Test adalah:

$\mathrm{H}_{\mathrm{o}}$ : Common effectmodel (CEM) lebih baik dari random effectmodel (REM)

$\mathrm{H}_{1}$ : Random effectmodel (REM) lebih baik dari common effectmodel (CEM)

5. Dengan kriteria pengujian jika $X^{2}{ }_{\text {hitung }} \geq X^{2}$ tabel dan $p$-value signifikan, maka $\mathrm{H}_{\mathrm{o}}$ ditolak, artinya model REM lebih tepat digunakan (Gujarati, 2003).Pengujian Hipotesa Penelitian Pengujian hipotesis digunakan untuk mengetahui pengaruh variabel independen $(X)$ dengan variabel dependen (Y) adalah menggunakan regresi linier data panel. Adapun langkahlangkah analisis ini adalah sebagai berikut: 
a. Uji Parsial (Uji t)

Uji $t$ pada dasarnya menunjukkan seberapa jauh pengaruh satu variabel independen secara individual dalam menerangkan variasi variabel dependen. Uji $t$ digunakan untuk menguji koefisien regresi secara parsial dari variabel independennya. Prosedur yang digunakan untuk melakukan uji $t$ adalah:

a. Merumuskan hipotesis

$\mathrm{H}_{\mathrm{i}} ; \beta_{1}=\beta_{2}=\beta_{3} \neq 0$, artinya bahwa terdapat pengaruh yang signifikan dari variabel independen terhadap variabel dependen secara parsial.

b. Menentukan tingkat signifikasi

Hipotesis ini diuji dengan menggunakan tingkat signifikasi sebesar $\alpha=0,05$.

c. Menetukan kriteria pengujian hipotesis penelitian:

1) Berdasarkan perbandingan thitung dengan t-tabel dengan pedoman:

a) Jika $\mathrm{t}_{\text {hitung }}<\mathrm{t}_{\text {tabel }}$, berarti variabel independent secara signifikan parsial tidak mempunyai pengaruh yang signifikan terhadapvariabel dependent

b) Jika $t_{\text {hitung }} \geq \mathrm{t}_{\text {tabel }}$, berarti variabel independent secara parsial mempunyai pengaruh yang signifikan terhadap variabel dependent

2) Berdasarkan niali signifikasi ( $p$-value), pedomannya ialah :

a) Apabila nilai signifikasi ( $p$-value) $>0,05$ : berarti variabel independent secara parsial tidak mempunyai pengaruh yang signifikan terhadap variabel dependent.

b) Apabila nilai signifikasi ( $p$-value $) \leq 0,05$ : berarti variabel independent secara parsial mempunyai pengaruh yang signifikan terhadap variabel dependent.

b. Uji Simultan (Uji F)

Uji $\mathrm{F}$ digunakan untuk mengetahui ada tidaknya pengaruh secara bersama-sama (simultan) antar variabel bebas terhadap variabel terikat. Prosedur yang digunakan untuk melakukan uji $\mathrm{F}$ adalah:

a. Merumuskan hipotesis

$\mathrm{H}_{\mathrm{i}} ; \beta_{1}=\beta_{2}=\beta_{3}: \neq 0$, artinya bahwa terdapat pengaruh yang signifikan dari variabel independen terhadap variabel dependen secara simultan.

b. Menentukan tingkat signifikasi

Hipotesis ini diuji dengan menggunakan tingkat signifikasi sebesar $\alpha=0,05$.

c. Menentukan kriteria pengujian hipotesis penelitian

1) Berdasarkan perbandingan $F_{\text {hitung }}$ dengan $F_{\text {tabel }}$ dengan pedoman:

a) Jika $\mathrm{F}_{\text {hitung }}<F_{\text {tabel, }}$, berarti semua variabel independent secara simultan tidak mempunyai pengaruh yang signifikan terhadap variabel dependent

b) Jika $\mathrm{F}_{\text {hitung }} \geq F_{\text {tabel, }}$, berarti semua variabel independent secara simultan mempunyai pengaruh yang signifikan terhadap variabel dependent

2) Berdasarkan nilai signifikan ( $p$-value), pedomannya ialah:

a) Apabila nilai signifikasi ( $p$-value) $>0,05$ : berarti semua variabel independent secara simultan tidak mempunyai pengaruh yang signifikan terhadap variabel dependent.

b) Apabila nilai signifikasi $(p$-value $) \leq 0,05$ : berarti semua variabel independent secara simultan mempunyai pengaruh yang signifikan terhadap variabel dependent.

c. Koefisien Determinasi $\left(R^{2}\right)$

Koefisien determinasi $\left(R^{2}\right)$ digunakan untuk mengukur seberapa jauh kemampuan model dalam menerangkan variasi variabel dependen (Gujarati, 2003). Nilai koefisien determinasi adalah 0 dan 1 . Nilai $R^{2}$ yang kecil berarti kemampuan variabelvariabel independen dalam menjelaskan variasi variabel dependen amat terbatas (Ghozali, 2013). Nilai yang mendekati 1 (satu) berarti variabel-variabel independen memberikan hampir semua informasi yang dibutuhkan untuk memprediksi variasi variabel dependen. 


\section{HASIL DAN PEMBAHASAN}

Selama periode penelitian, seperti yang dapat dilihatpada Tabel 11, hasil penelitian memperlihatkan bahwa nilai rata-rata efisiensi teknis bank pemerintah di Indonesia adalah sebesar 99,5persen. Bank umum swasta nasional devisa (BUSND) di Indonesia sebesar 92,0 persen, sedangkan nilai rata-rata efisiensi teknis bank umum swasta nasional non-devisa (BUSNND) di Indonesia sebesar 94,4 persen. Kemudian nilai rata-rata efisiensi teknis bank pembangunan daerah (BPD) di Indonesia sebesar 100 persen.

Tabel 1. Nilai Efisiensi DEA

\begin{tabular}{llcccc}
\hline \multicolumn{1}{c}{ Kelompok Bank } & Efisiensi & Minimum & Maksimum & Mean & $\begin{array}{c}\text { Std. } \\
\text { Deviasi }\end{array}$ \\
\hline \multirow{3}{*}{ Bank pemerintah } & CRS TE & 0,984 & 1,000 & 0,995 & 0,008 \\
& VRS TE & 1,000 & 1,000 & 1,000 & 0,000 \\
& SE & 0,984 & 1,000 & 0,995 & 0,008 \\
Bank umum swasta nasional devisa & CRS TE & 0,631 & 1,000 & 0,920 & 0,131 \\
& VRS TE & 0,691 & 1,000 & 0,957 & 0,092 \\
& SE & 0,762 & 1,000 & 0,958 & 0,073 \\
Bank umum swasta nasional non- & CRS TE & 0,823 & 1,000 & 0,944 & 0,073 \\
devisa & VRS TE & 1,000 & 1,000 & 1,000 & 0,000 \\
& SE & 0,820 & 1,000 & 0,943 & 0,074 \\
Bank pembangunan daerah & CRS TE & 1,000 & 1,000 & 1,000 & 0,000 \\
& VRS TE & 1,000 & 1,000 & 1,000 & 0,000 \\
& SE & 1,000 & 1,000 & 1,000 & 0,000 \\
\hline
\end{tabular}

Sumber: Hasil Pengolahan dengan DEAP 2.1p

Keterangan:

CRSpTE : Technical EfficiencyChange

VRS PE : Pure Technical Efficiency

SEp : Scale Efficiency

Pada Tabel 2 menunjukkan bank-bank umum persero (Pemerintah), bank umum swasta nasional devisa (BUSND), bank umum swasta nasional non-devisa (BUSNND), dan bank pembangunan daerah (BPD) yang berada pada frontier efisiensi DEA menunjukkan jumlah bank yang paling efisien (memiliki efisiensi 100 persen) dan sudah beroperasi pada skala optimal bervariasi antara 11 sampai 21 bank. Selama periode penelitian hampir semua bank baik pemerintah, bank swasta nasional devisa (BSND), bank swasta nasional non-devisa (BSNND), dan bank pembangunan daerah (BPD) berada pada frontier setidaknya satu kali, dengan hanya dua bank dari kelompok bank swasta nasional devisa (BSND) yang tidak pernah berada pada frontier efisiensi selama periode penelitian yaitu bank Mega Tbk., dan Bank OCBCNISP Tbk. Sementara itu, semua bank pada kelompok bank pemerintah, bank swasta nasional non-devisa, dan bank pembangunan daerah sudah berada pada frontier efisiensi selama periode penelitian. 
Tabel 2. Komposisi Frontier Produksi

\begin{tabular}{|c|c|c|c|c|c|c|c|}
\hline Nama Bank & $\begin{array}{c}\text { Kelompok } \\
\text { Bank }\end{array}$ & 2013 & 2014 & 2015 & 2016 & 2017 & Jumlah \\
\hline PT. Bank Negara Indonesia (Persero) Tbk & Pemerintah & drs & crs & drs & crs & irs & 2 \\
\hline PT. Bank Rakyat Indonesia (Persero) Tbk & Pemerintah & crs & crs & crs & crs & drs & 4 \\
\hline PT. Bank Tabungan Negara (Persero) Tbk & Pemerintah & crs & crs & crs & crs & crs & 5 \\
\hline PT. Bank Mandiri (Persero) Tbk & Pemerintah & crs & crs & crs & crs & crs & 5 \\
\hline PT. Bank Rakyat Indonesia Agroniaga Tbk & BUSND & irs & irs & crs & crs & drs & 2 \\
\hline PT. Bank Capital Inodesia Tbk & BUSND & irs & irs & irs & crs & irs & 1 \\
\hline PT. Bank Central Asia Tbk & BUSND & drs & drs & crs & crs & drs & 2 \\
\hline PT. Bank Bukopin Tbk & BUSND & drs & drs & drs & drs & crs & 1 \\
\hline PT. Bank Mestika Dharma Tbk & BUSND & drs & crs & crs & crs & crs & 4 \\
\hline PT. Bank Danamon Indonesia Tbk & BUSND & crs & crs & irs & irs & drs & 2 \\
\hline PT. Bank Maspion Indonesia Tbk & BUSND & irs & irs & crs & crs & crs & 3 \\
\hline PT. Bank Bumi Arta Tbk & BUSND & irs & irs & irs & irs & crs & 1 \\
\hline PT. Bank Cimb Niaga Tbk & BUSND & $\mathrm{drs}$ & drs & drs & crs & crs & 2 \\
\hline PT. Bank Maybank Indonesia Tbk & BUSND & drs & crs & crs & irs & crs & 3 \\
\hline PT. Bank Permata Tbk & BUSND & drs & drs & irs & crs & drs & 1 \\
\hline PT. Bank Sinarams Tbk & BUSND & crs & crs & crs & irs & crs & 4 \\
\hline PT. Bank Artha Graha Internasional Tbk & BUSND & drs & drs & drs & crs & irs & 1 \\
\hline PT. Bank Mayapada Internasional Tbk & BUSND & drs & drs & crs & irs & drs & 1 \\
\hline PT. Bank Windu Kentjana Internasional Tbk & BUSND & drs & irs & drs & crs & crs & 2 \\
\hline PT. Bank Mega Tbk & BUSND & drs & drs & drs & drs & drs & 0 \\
\hline PT. Bank OCBC NISP Tbk & BUSND & drs & drs & drs & drs & drs & 0 \\
\hline PT. Bank Pan Indonesia Tbk & BUSND & drs & drs & crs & crs & drs & 1 \\
\hline PT. Bank Woori Saudara Indonesia 1906 Tbk & BUSND & crs & crs & crs & crs & crs & 5 \\
\hline PT. Bank Yudha Bhakti Tbk & BUSND & crs & crs & crs & irs & crs & 4 \\
\hline PT. Bank Tabungan Pensiun Nasional Tbk & BUSND & crs & crs & crs & crs & crs & 5 \\
\hline PT. Bank Victoria Internasional Tbk & BUSND & crs & crs & crs & crs & crs & 5 \\
\hline PT. Bank MItraniaga Tbk & BUSND & irs & irs & irs & crs & crs & 2 \\
\hline PT. Bank Nationalnobu Tbk & BUSND & irs & irs & drs & crs & crs & 2 \\
\hline PT. Bank Pembangunan Daerah Jawa Barat dan Banten Tbk & BPD & crs & crs & crs & crs & crs & 5 \\
\hline PT. Bank Pembangunan Daerah Jawa Timur Tbk & BPD & crs & crs & crs & crs & crs & 5 \\
\hline Jumlah Bank & 30 & 11 & 14 & 17 & 21 & 18 & \\
\hline
\end{tabular}

Sumber: Hasil Pengolahan dengan DEAP 2.1

Keterangan:

CRSo : Constant Returns to Scale

VRS : Decreasing Returns to Scale

IRS : IncreasingReturn to Scale

Berdasarkan hasil pengujian Efisiensi Industri Perbankan yang Terdaftar di BEI dengan DEA seperti terlihat pada Tabel 1, maka dapat diketahui bahwa dari keempat kelompok bank yaitu kelompok bank umum persero (Pemerintah), bank umum swasta nasional devisa (BUSND), bank umum swasta nasional non-devisa (BUSNND), dan bank pembangunan daerah (BPD) memiliki tingkat efisiensi yang berbeda-beda. Mengacu pada Tabel 2, selama tahun pengamatan yaitu 2013 sampai dengan 2017, maka pada kelompok bank swasta nasional devisa (BSND) dengan jumlah bank sebanyak 19 bank sebanyak dua bank yang tidak pernah berada pada frontier efisiensi selama periode 2013 sampai 2017 yaitu bank Mega Tbk, dan Bank OCBCNISP Tbk. Sementara itu, semua bank pada kelompok bank pemerintah, bank swasta nasional non-devisa, dan bank pembangunan daerah sudah berada pada frontier efisiensi selama periode penelitian. Dengan demikian dapat dibuatkan tabel kesimpulan mengenai tingkat efisiensi dari keempat kelompok bank tersebut seperti Tabel 3 berikut ini. 
Tabel 3. Nilai Efisiensi Lembaga Keuangan Bank di BEI Tahun 2013 - 2017

\begin{tabular}{|c|c|c|c|c|c|c|c|c|c|c|c|}
\hline \multirow[b]{2}{*}{ Nama Bank } & \multirow[b]{2}{*}{$\begin{array}{l}\text { Kode } \\
\text { Bank }\end{array}$} & \multirow{2}{*}{$\begin{array}{c}2013 \\
\text { Nilai } \\
\text { Efisiensi }\end{array}$} & \multirow[b]{2}{*}{ Ket. } & \multicolumn{2}{|l|}{2014} & \multirow{2}{*}{$\begin{array}{c}2015 \\
\text { Nilai } \\
\text { Efisiensi }\end{array}$} & \multirow[b]{2}{*}{ Ket. } & \multirow{2}{*}{$\begin{array}{c}2016 \\
\text { Nilai } \\
\text { Efisiensi }\end{array}$} & \multicolumn{3}{|c|}{2017} \\
\hline & & & & $\begin{array}{c}\text { Nilai } \\
\text { Efisiensi }\end{array}$ & Ket. & & & & Ket. & $\begin{array}{c}\text { Nilai } \\
\text { Efisiensi }\end{array}$ & Ket. \\
\hline $\begin{array}{l}\text { PT. Bank Negara Indonesia } \\
\text { (Persero) Tbk }\end{array}$ & BBNI & 0,841 & $\mathrm{TE}$ & 0,912 & $\mathrm{TE}$ & 0,945 & $\mathrm{TE}$ & 0,888 & $\mathrm{TE}$ & 0,902 & $\mathrm{TE}$ \\
\hline $\begin{array}{l}\text { PT. Bank Rakyat Indonesia } \\
\text { (Persero) Tbk }\end{array}$ & BBRI & 0,882 & $\mathrm{TE}$ & 0,825 & $\mathrm{TE}$ & 0,852 & $\mathrm{TE}$ & 0,849 & $\mathrm{TE}$ & 0,869 & $\mathrm{TE}$ \\
\hline $\begin{array}{l}\text { PT. Bank Tabungan Negara } \\
\text { (Persero) Tbk }\end{array}$ & BBTN & 0,890 & $\mathrm{TE}$ & 1,000 & $\mathrm{E}$ & 1,000 & $\mathrm{E}$ & 1,000 & $\mathrm{E}$ & 1,000 & $\mathrm{E}$ \\
\hline PT. Bank Mandiri (Persero) Tbk & BMRI & 0,806 & $\mathrm{TE}$ & 0,883 & TE & 0,941 & TE & 0,857 & TE & 0,896 & TE \\
\hline $\begin{array}{l}\text { PT. Bank Rakyat Indonesia } \\
\text { Agroniaga Tbk }\end{array}$ & AGRO & 0,970 & $\mathrm{TE}$ & 0,992 & $\mathrm{TE}$ & 0,998 & $\mathrm{TE}$ & 1,000 & E & 0,945 & $\mathrm{TE}$ \\
\hline PT. Bank Capital Inodesia Tbk & BACA & 0,971 & $\mathrm{TE}$ & 0,986 & $\mathrm{TE}$ & 0,861 & $\mathrm{TE}$ & 0,885 & $\mathrm{TE}$ & 0,883 & TE \\
\hline PT. Bank Central Asia Tbk & $\mathrm{BBCA}$ & 0,783 & $\mathrm{TE}$ & 0,871 & $\mathrm{TE}$ & 1,000 & $\mathrm{E}$ & 0,998 & $\mathrm{TE}$ & 0,978 & $\mathrm{TE}$ \\
\hline PT. Bank Bukopin Tbk & BBKP & 0,899 & TE & 1,000 & & 0,999 & $\mathrm{TE}$ & 0,966 & TE & 0,972 & TE \\
\hline PT. Bank Mestika Dharma Tbk & BBMD & 0,987 & $\mathrm{TE}$ & 1,000 & $\mathrm{E}$ & 1,000 & $\mathrm{E}$ & 0,999 & $\mathrm{TE}$ & 0,982 & $\mathrm{TE}$ \\
\hline $\begin{array}{l}\text { PT. Bank Danamon Indonesia } \\
\text { Tbk }\end{array}$ & BDMN & 1,000 & $\mathrm{E}$ & 0,980 & $\mathrm{TE}$ & 0,962 & $\mathrm{TE}$ & 0,996 & $\mathrm{TE}$ & 1,000 & $\mathrm{E}$ \\
\hline $\begin{array}{l}\text { PT. Bank Maspion Indonesia } \\
\text { Tbk }\end{array}$ & BMAS & 0,941 & $\mathrm{TE}$ & 0,987 & $\mathrm{TE}$ & 0,998 & $\mathrm{TE}$ & 0,995 & $\mathrm{TE}$ & 0,989 & $\mathrm{TE}$ \\
\hline PT. Bank Bumi Arta Tbk & BNBA & 0,935 & $\mathrm{TE}$ & 0,991 & $\mathrm{TE}$ & 0,987 & $\mathrm{TE}$ & 0,995 & $\mathrm{TE}$ & 0,995 & $\mathrm{TE}$ \\
\hline PT. Bank Cimb Niaga Tbk & BNGA & 0,870 & $\mathrm{TE}$ & 0,978 & $\mathrm{TE}$ & 0,946 & $\mathrm{TE}$ & 0,945 & $\mathrm{TE}$ & 0,946 & $\mathrm{TE}$ \\
\hline $\begin{array}{l}\text { PT. Bank Maybank Indonesia } \\
\text { Tbk }\end{array}$ & BNII & 0,905 & $\mathrm{TE}$ & 1,000 & $\mathrm{E}$ & 1,000 & $\mathrm{E}$ & 1,000 & $\mathrm{E}$ & 1,000 & $\mathrm{E}$ \\
\hline PT. Bank Permata Tbk & BNLI & 0,877 & $\mathrm{TE}$ & 0,894 & $\mathrm{TE}$ & 0,990 & TE & 0,812 & TE & 0,841 & $\mathrm{TE}$ \\
\hline PT. Bank Sinarams Tbk & BSIM & 1,000 & $\mathrm{E}$ & 1,000 & $\mathrm{E}$ & 1,000 & $\mathrm{E}$ & 1,000 & $\mathrm{E}$ & 1,000 & $\mathrm{E}$ \\
\hline $\begin{array}{l}\text { PT. Bank Artha Graha } \\
\text { Internasional Tbk }\end{array}$ & INPC & 0,932 & $\mathrm{TE}$ & 0,992 & $\mathrm{TE}$ & 0,982 & TE & 0,981 & $\mathrm{TE}$ & 0,972 & $\mathrm{TE}$ \\
\hline $\begin{array}{l}\text { PT. Bank Mayapada } \\
\text { Internasional Tbk }\end{array}$ & MAYA & 0,931 & $\mathrm{TE}$ & 0,999 & TE & 1,000 & $\mathrm{E}$ & 1,000 & $\mathrm{E}$ & 1,000 & E \\
\hline $\begin{array}{l}\text { PT. Bank Windu Kentjana } \\
\text { Internasional Tbk }\end{array}$ & MCOR & 0,990 & $\mathrm{TE}$ & 0,995 & $\mathrm{TE}$ & 0.994 & $\mathrm{TE}$ & 0,989 & $\mathrm{TE}$ & 0,988 & $\mathrm{TE}$ \\
\hline PT. Bank Mega Tbk & MEGA & 0,904 & TE & 0,992 & TE & 0,999 & TE & 1,000 & $\mathrm{E}$ & 0,999 & TE \\
\hline PT. Bank OCBC NISP Tbk & NISP & 0,865 & TE & 0,988 & TE & 0,995 & TE & 0,958 & TE & 0,966 & TE \\
\hline PT. Bank Pan Indonesia Tbk & PNBN & 0,809 & TE & 0,945 & TE & 0,998 & TE & 0,991 & $\mathrm{TE}$ & 1,000 & $\mathrm{E}$ \\
\hline $\begin{array}{l}\text { PT. Bank Woori Saudara } \\
\text { Indonesia } 1906 \text { Tbk }\end{array}$ & SDRA & 1,000 & $\mathrm{E}$ & 1,000 & $\mathrm{E}$ & 0,979 & $\mathrm{TE}$ & 1,000 & $\mathrm{E}$ & 1,000 & $\mathrm{E}$ \\
\hline PT. Bank Yudha Bhakti Tbk & BBYB & 0,821 & $\mathrm{TE}$ & 0,976 & $\mathrm{TE}$ & 1,000 & $\mathrm{E}$ & 1,000 & E & 1,000 & $\mathrm{E}$ \\
\hline $\begin{array}{l}\text { PT. Bank Tabungan Pensiun } \\
\text { Nasional Tbk }\end{array}$ & BTPN & 1,000 & $\mathrm{E}$ & 1,000 & E & 1,000 & E & 1,000 & E & 1,000 & $\mathrm{E}$ \\
\hline $\begin{array}{l}\text { PT. Bank Victoria Internasional } \\
\text { Tbk }\end{array}$ & BVIC & 0,921 & $\mathrm{TE}$ & 0,997 & $\mathrm{TE}$ & 0,977 & TE & 0,969 & TE & 0,929 & $\mathrm{TE}$ \\
\hline PT. Bank MItraniaga Tbk & NAGA & 0,039 & $\mathrm{TE}$ & 0,069 & $\mathrm{TE}$ & 0,100 & $\mathrm{TE}$ & 0,094 & $\mathrm{TE}$ & 0,046 & $\mathrm{TE}$ \\
\hline PT. Bank Nationalnobu Tbk & NOBU & 0,635 & $\mathrm{TE}$ & 0,841 & $\mathrm{TE}$ & 0,877 & $\mathrm{TE}$ & 0,905 & $\mathrm{TE}$ & 0,900 & $\mathrm{TE}$ \\
\hline $\begin{array}{l}\text { PT. Bank Pembangunan Daerah } \\
\text { Jawa Barat dan Banten Tbk }\end{array}$ & BJBR & 0,816 & $\mathrm{TE}$ & 0,991 & $\mathrm{TE}$ & 0,992 & $\mathrm{TE}$ & 0,959 & $\mathrm{TE}$ & 0,969 & $\mathrm{TE}$ \\
\hline $\begin{array}{l}\text { PT. Bank Pembangunan Daerah } \\
\text { Jawa Timur Tbk }\end{array}$ & BJTM & 0,909 & $\mathrm{TE}$ & 0,973 & $\mathrm{TE}$ & 0,978 & $\mathrm{TE}$ & 0,983 & $\mathrm{TE}$ & 0,976 & $\mathrm{TE}$ \\
\hline
\end{tabular}

\section{Keterangan:}

\section{E : Efisien}

TE : Tidak Efisien

Berdasarkan uji pemilihan model dalam regresi data panel, dihasilkan random effect model sebagai model terbaik, dengan output pada Tabel 4.

Tabel 4. Analisis Regresi Data Panel

Dependent Variable: EFISIENSI?

Method: Pooled EGLS (Cross-section random effects)

\begin{tabular}{crrrr}
\hline Variable & Coefficient & Std. Error & \multicolumn{1}{c}{ t-Statistic } & \multicolumn{1}{l}{ Prob. } \\
\hline C & 0,188996 & 8,859464 & 0,021333 & 0,9830 \\
SIZE? & 0,007762 & 0,008293 & 2,935888 & 0,0410 \\
CAR? & 0,338741 & 0,150427 & 2,251873 & 0,0260 \\
NPL? & $-0,255019$ & 0,072465 & $-3,519219$ & 0,0006 \\
LDR? & 0,490360 & 0,053579 & 9,152093 & 0,0000 \\
KURS? & 0,026126 & 0,251401 & 0,103921 & 0,9174 \\
SBI? & 0,000728 & 0,014861 & 0,048957 & 0,9610 \\
GDP? & 0,011519 & 0,484149 & 0,023792 & 0,9811 \\
\hline Adjusted R-squared & 0,337280 & & & \\
F-statistic & 11,10596 & & & \\
Prob(F-statistic) & 0,000000 & & &
\end{tabular}


Berdasarkan Tabel 4, diperoleh persamaan regresi sebagai berikut:

EFISIENSI $=0,188996-0,007762$ SIZE $-0,338741 \mathrm{CAR}+0,255019 \mathrm{NPL}+0,490360 \mathrm{LDR}+$ $0,26126 \mathrm{KURS}+0,000728 \mathrm{SBI}+0,011519 \mathrm{GDP}+\mathrm{e}$

Berdasarkan Tabel 4 diatas, nilai adjusted $R$-Squared adalah sebesar 0,33720. Hal ini dapat diartikan bahwa variabel-variabel bebasdalam penelitian ini, yaitu ukuran bank (SIZE), Capital Adequacy Ratio (CAR), Non Performing Loan (NPL), nilai tukar rupiah terhadap Dollar Amerika (KURS), suku bunga Bank Indonesia (SBI) dan Gross Domestic Product (GDP) perusahaan secara bersama-sama dapat menjelaskan variabel terikat, yaitu efisiensi bank sebesar 33,72 persen. Sisanya sebesar 66,28 persen dijelaskan oleh variabel-variabel lain diluar model penelitian.

Selanjutnya berdasarkan uji T-Parsial diperoleh hasil bahwa ukuran bank (SIZE) memiliki nilai estimate diperoleh sebesar 0,007762 , dan nilai $p$-value sebesar $0,0410<0,05$ (tingkat kesalahan $\alpha=5$ persen), maka $\mathrm{H}_{\mathrm{a}} 1$ diterima. Dapat disimpulkan bahwa ukuran bank (SIZE) berpengaruh positif terhadap efisiensi bank. Hal ini menunjukkan bahwa besar kecilnya ukuran bank dapat mempengaruhi efisiensi bank. Hasil ini sejalan dengan temuan penelitian yang dilakukan oleh Yudhistira (2004), Subekti dan Widiyanti (2004), Acsarya dan Yumanita (2005), dan Herlina (2006) yang menemukan adanya hubungan positif dengan tingkat efisiensi bank.

Sedangkan pada variabel Capital Adequacy Ratio (CAR) memiliki nilai estimate diperoleh sebesar 0,338741, dan nilai $p$-value sebesar 0,0260<0,05 (tingkat kesalahan $\alpha=5$ persen), maka $\mathrm{Ha} 2$ diterima. Dapat disimpulkan bahwa Capital Adequacy Ratio (CAR) berpengaruh positif terhadap efisiensi bank. Hal ini dikarenakan bahwa kemampuan bank dalam mencukupi modalnya akan memberikan peluang yang cukup besar bagi suatu bank untuk melakukan ekspansi kredit (memaksimalkan output) yang akan berpengaruh terhadap tingkat efisiensi bank tersebut. Hasil penelitian ini sejalan dengan penelitian sebelumnya Berger dan Mester (1997) serta didukung hasil penelitian terbaru oleh Fatmawati dan Aji (2018)bahwa faktor CAR berpengaruh positif signifikan terhadapefisiensi.

Hipotesis ketiga pada variabel Non Performing Loan (NPL) memilikinilai estimate diperoleh sebesar -0,255019, dan nilai $p$-value sebesar 0,0006 < 0,05 (tingkat kesalahan $\alpha=$ 5\%), maka $\mathrm{H}_{\mathrm{a}} 3$ diterima. Dapat disimpulkan bahwa Non Performing Loan (NPL) berpengaruh dengan arah hubungan negatif terhadap efisiensi bank. Hal ini menunjukkan bahwa besarnya Non Performing Loan (NPL) akan diikuti oleh menurunnya tingkat efisiensi bank. Kondisi ini mengindikasikan bahwa apabila nilai NPL tinggi dapat dijadikan sebagai indikasi tingginya jumlah kredit yang bermasalah. Hasil penelitian ini sejalan dengan penelitian terdahulu yang dilakukan oleh Ramli et al. (2018) yang juga menemukan bahwa Non Performing Loan memiliki pengaruh signifikan dengna arah hubungan negatif terhadap efisiensi.

Variabel loan to deposit ratio (LDR) memilikinilai estimate diperoleh sebesar 0,490360, dan nilai $p$-value sebesar $0,0000<0,05$ (tingkat kesalahan $\alpha=5$ persen), maka Ha4 diterima. Dapat disimpulkan bahwa loan to deposit ratio (LDR) berpengaruh positif terhadap efisiensi bank. Penelitian terdahulu yang dilakukan oleh Subandi dan Ghozali (2014) menyatakan adanya hubungan positif signifikanantara LDR dengan tingkat efisiensi perbankan. Dimana bank-bank yang menunjukkan kinerja LDR yang optimal lebih efisien dibandingkan bank dengan LDR rendah.

Hipotesis kelima pada variabel nilai tukar rupiah terhadap Dollar Amerika (KURS) nilai estimate diperoleh sebesar 0,026126, dan nilai p-value sebesar 0,9174>0,05 (tingkat kesalahan $\alpha=5 \%$ ), maka Ho5 diterima dan Ha5 ditolak. Dapat disimpulkan bahwa nilai tukar rupiah terhadap Dollar Amerika (KURS) tidak berpengaruh negatif terhadap efisiensi bank.Hasil ini mengindikasikan bahwa nilai tukar rupiah terhadap dollar Amerika dan suku bunga bank Indonesia tidak sepenuhnya memberikan pengaruh yang berarti terhadap perubahan naik turunnya tingkat efisiensi bank umum persero (Pemerintah), bank umum swasta nasional devisa (BUSND), bank umum swasta nasional non-devisa (BUSNND), dan bank pembangunan daerah (BPD). 
Suku bunga Bank Indonesia (SBI) memiliki nilai estimate diperoleh sebesar 0,000728, dan nilai $p$-value sebesar $0,9610>0,05$ (tingkat kesalahan $\alpha=5$ persen), maka Ha6 ditolak. Dapat disimpulkan bahwa suku bunga Bank Indonesia (SBI) tidak berpengaruh negatif terhadap efisiensi bank. Hal ini menunjukkan bahwa besar kecilnya tingkat suku bunga Bank Indonesia (SBI) tidak berpengaruh terhadap efisiensi bank. Hasil ini mengindikasikan bahwa nilai tukar rupiah terhadap dollar Amerika dan suku bunga bank Indonesia tidak sepenuhnya memberikan pengaruh yang berarti terhadap perubahan naik turunnya tingkat efisiensi bank.

Variabel gross domestic product (GDP) memiliki nilai estimate diperoleh sebesar 0,011519 , dan nilai $p$-value sebesar 0,9811 >0,05 (tingkat kesalahan $\alpha=5$ persen), maka Ha7 ditolak. Dapat disimpulkan bahwa grossdomestic product (GDP) tidak berpengaruh negatif terhadap efisiensi bank. Hasil ini sesuai dengan Sparta (2017) bahwa meskipun nominal GDP Indonesia terus naiksetiap tahunnya, pertumbuhan GDP tersebut terus mengalami penurunan. Penurunan persentase pertumbuhan ekonomi tidak memiliki nilai range yang besar, sedangkan tingkat efisiensi perbankan bergerak fluktuatif dengan nilai yang beragam antar bank satu dengan bank yang lainnya.

Berdasarkan hasil pengujian mengenai tingkat efisiensi perbankan menggunakan DEA, diketahui bahwa Berdasarkan hasil analisis DEA dengan melihat nilai skala efisiensi (scale efficiency) diketahui bahwa bank yang memiliki nilai efisiensi 1 (satu) atau 100 persen selama periode pengamatan yaitu 2013 sampai dengan 2017 pada kelompok bank umum swasta nasional non-devisa yaitu PT. Bank Tabungan Pensiunan Nasional Tbk. Sementara itu, pada kelompok bank swasta nasional devisa hanya PT. Bank Sinarmas Tbk. yang memiliki nilai efisiensi 1 (satu) atau 100 persen selama periode pengamatan yaitu 2013 sampai dengan 2017. Sedangkan pada kelompok bank bank pemerintah, dan bank umum swasta nasional devisa efisiensi terjadi tidak sepenuhnya dalam tahun tahun pengamatan. Hal tersebut dapat dilihat pada grafik berikut:

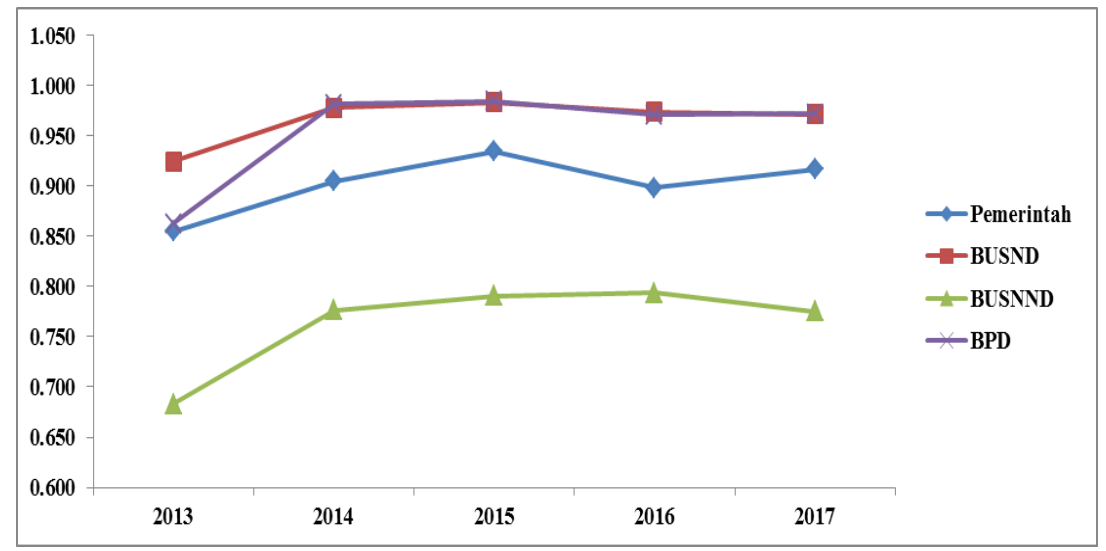

Gambar 7. Trend efisiensi per kelompok bank periode 2013-2017 Sumber: Hasil Olah Data dengan DEAP

Hasil tersebut menunjukkan bahwa tingkat efisiensi berdasarkan kelompok bank ratarata efisiensi telah dicapai oleh kelompok bank umum swasta devisa. Sementara itu, kelompok bank umum swasta nasional non-devisa merupakan kelompok bank yang memiliki rata-rata tingkat efisiensi paling rendah dibandingkan dengan kelompok bank lainnya dalam pengamatan ini. Hal ini dapat terjadi karena pada kelompok bank swasta nasional devisa rata-rata memiliki modal besar dan memiliki teknologi dan jaringan yang luas. Lebih lanjut, berdasarkan pengertian bank devisa yang disebutkan dalam penelitian Azis (2015) bahwa bank devisa merupakan bank yang dapat melaksanakan transaksi keluar negeri atau yang berhubungan dengan mata uang asing secara keseluruhan. Sehingga rata-rata bank pada kelompok devisa ini menjaga tingkat kinerja banknya untuk dapat bersaing dalam persaiangan global. Dengan kata lain, bank devisa dinilai memiliki jaringan bank yang sangat besar dan luas sehingga memiliki kinerja yang lebih bagus serta manajemen yang berskala internasional, yang membuat bank tersebut memiliki kinerja yang bagus juga. Sedangkan kelompok bank lainnya seperti kelompok 
bank swasta nasional non-devisa dinilai belum efisien karena sebagian besar bank yang masuk dalam kelompok bank tersebut adalah kelompok bank yang memiliki modal kecil dan memiliki jaringan yang terbatas juga. Untuk kelompok bank swasta nasional non-devisa, kelompok bank ini tidak dapat melakukan kegiatan transaksi dengan pihak luar negeri atau dengan valuta asing, sehingga fungsi bank sebagai lembaga intermediasi juga terbatas.

\section{KESIMPULAN}

Berdasarkan hasil pengujian maka dapat dibuatkan beberapa kesimpulan penelitian terkait dengan efisiensi perbankan serta pengaruh faktor internal dan eskternal dalam mempengaruhi tingkat efisiensi perbankan. Berdasarkan hasil analisis DEA dengan melihat nilai skala efisiensi diketahui bahwa bank yang memiliki nilai efisiensi 1 (satu) atau 100 persen selama periode pengamatan yaitu periode 2013-2017 pada kelompok bank umum swasta nasional non-devisa yaitu PT. Bank Tabungan Pensiunan Nasional Tbk., Sementara itu, pada kelompok bank swasta nasional devisa hanya PT. Bank Sinarmas Tbk. yang memiliki nilai efisiensi 1 (satu) atau 100 persen selama periode pengamatan yaitu 2013 sampai dengan 2017. Sedangkan pada kelompok bank bank pemerintah, dan bank umum swasta nasional devisa efisiensi terjadi tidak sepenuhnya dalam tahun pengamatan.

Ukuran bank (SIZE), Capital adequacy ratio(CAR), dan Loan toodeposit ratio (LDR) terbukti signifikan berpengaruh positif terhadap efisiensi perbankan yang terdaftar di Bursa Efek Indonesia periode 2013-2017.Non PerformingLoan (NPL) terbukti signifikan berpengaruh negatif terhadap efisiensi perbankan yang terdaftar di Bursa Efek Indonesiaperiode 2013-2017. Faktor eksternal seperti nilai tukar rupiahh (KURS), Suku bunga Bank Indonesia (SBI), dan Gross Domestic Product (GDP) terbukti tidak signifikan berpengaruh positif terhadap efisiensi perbankan yang terdaftar di Bursa Efek Indonesia periode 2013-2017.

\section{DAFTAR PUSTAKA}

Andhyka, B., Nisa, C., \& Puwoko, B. (2017). Penggunaan BUKU dan Kepemilikan dalam Menganalisis Efisiensi Perbankan di Indonesia. Al Tijarah, 3(2), 1-22.

Anwar, Mo., Duygun, M., \& Shaban, M. (2012). Small Business Finance and Indonesian Banks Efficiency: DEA Approach, The 13th International Convention of The East Asian Economic Association.

Azis, A. (2015). Analisis Perbandingan Kinerja Keuangan bank Devisa dan Bank Non-Devisa di Indonesia. Jom FEKON, 2(1), 1-15.

Banker, RD, Charnes, A. \& Cooper, WW. (1984). Some models for estimating technical and scale inefficiencies in data envelopment analysis. Management Science, 30(9), 10781092.

Berger, A. N., \& Mester, L. J. (1997). Inside the black box: what explains differences in the efficiencies of financial institutions. Journal of Banking and Finance, 21(7), 895-947.

Berger C., Blauth, R.,\& Boger D. (1993). Kano Methods for Understanding Customer-Defined Quality, Hinshitsu: Journal of the Japanese Society for Quality Control.

Charnes, A., Cooper, W.W., \& Rhodes, E. (1978). Measuring the Efficiency of Decision Making Units. European Journal of Operational Research, 2(4), 429-444.

Endri, \&Abidin, Z. (2009). Kinerja Efisiensi Teknis Bank Pembangunan Daerah: Pendekatan Data Envelopment Analysis (DEA). Jurnal Akuntansi dan Keuangan, 11(1), 21-29.

Fatmawati, R., \& Aji, T. S. (2018). Analisis Pengaruh Faktor Internal dan Eksternal Terhadap Efisiensi Bank Umum Konvensional di Indonesia Periode 2012-2016 Dengan Menggunakan Two Stage Data Envelopment Analysis. Jurnal Ilmu Manajemen, 6(4), 367375.

Ghozali, I. (2013). Aplikasi Analisis Multivariat dengan Program IBM SPSS 21. Edisi 7 , Semarang: Penerbit Universitas Diponegoro.

Gujarati, D. (2003). Ekonometri Dasar. Jakarta: Erlangga. 
Hadad, M. D. Wimboh, S., Eugenia M., \& Dhaniel, I. (2003). Analisis Efisiensi Industri Perbankan Indonesia: Penggunaan Metode Nonparametrik Data Envelopment Analysis (DEA). Working Paper Series Bank Indonesia.

Kumar, M., \& Charles, V. (2012). Data Envelopment Analysis and Its Applications to Management. Newcastle Upon Tyne: Cambridge Scholars Publishing.

Muljawan, D., Hafidz, J., Astuti, R. I., dan Oktapiani, R. (2014). Faktor-faktor Penentu Efisiensi Perbankan Indonesia serta Dampaknya Terhadap Perhitungan Suku Bunga Kredit. Working paper Bank Indonesia wp/2/2014. Bank Indonesia.

Othman, F. M., Mohd-Zamil, N. A., Rasid, S. Z. A., Vakilbashi, A., \& Mokhber, M. (2016). Data Envelopment Analysis: A Tool of Measuring Efficiency in Banking Sector. International Journal of Economics and Financial Issues, 6(3), 911-916.

Ramli, N. A, Mohammed, N. I., Hussin, S. A. S., \& Khairi, S. S. M. (2018). Investigating The Effect of NonPerforming Loans on Technical Efficiency In Malaysian Banking Sector. AIP Conference Proceedings, 020008-1-020008-8.

Sparta. (2017). Analisis Pengaruh Efisiensi Dan Kecukupan Modal Terhadap Kinerja Keuangan Pada Bank Pembangunan Daerah di Indonesia. Jurnal Ekonomi dan Bisnis, 20(1), 87115 .

Subandi, \& Ghozali, I. (2014). A efficiency Determinant of Banking Industry in Indonesia. Research Journal of Finance and Accounting, 5(3), 2222-2487.

Subekti, I.,\& Widiyanti, N.W. (2004). Faktor-Faktor Yang Berpengaruh Terhadap Audit Delay di Indonesia. Simposium Nasional Akuntansi, 7, 991-1002.

Wijayanto, A., \& Sutarno. (2010). Kinerja Efisiensi Fungsi Intermediasi Bank Persero di Indonesia dengan Menggunakan Data Envelopment Analysis (DEA). Jurnal Keuangan dan Perbankan, 14(1), 110-121. 